\title{
SPATIAL VARIABILITY OF SOIL PROPERTIES IN AN AGRARIAN REFORM SETTLEMENT
}

\author{
James Ribeiro de Azevedo ${ }^{(1)^{*}}$, Célia Regina Paes Bueno ${ }^{(2)}$ and Gener Tadeu Pereira ${ }^{(3)}$
}

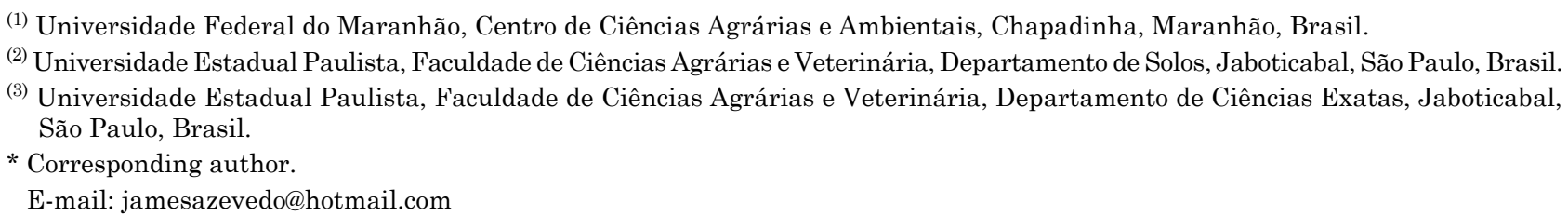

\begin{abstract}
The study of soil chemical and physical properties variability is important for suitable management practices. The aim of this study was to evaluate the spatial variability of soil properties in the Malhada do Meio settlement to subsidize soil use planning. The settlement is located in Chapadinha, MA, Brazil, and has an area of 630.86 ha. The vegetation is seasonal submontane deciduous forest and steppe savanna. The geology is formed of sandstones and siltstones of the Itapecuru Formation and by colluvial and alluvial deposits. The relief consists of hills with rounded and flat tops with an average altitude of $67 \mathrm{~m}$, and frequently covered over by ferruginous duricrusts. A total of 183 georeferenced soil samples were collected at the depth of 0.00-0.20 $\mathrm{m}$ in Plintossolos, Neossolo and Gleissolo. The following chemical variables were analyzed: $\mathrm{pH}\left(\mathrm{CaCl}_{2}\right), \mathrm{H}+\mathrm{Al}, \mathrm{Al}, \mathrm{SB}, \mathrm{V}, \mathrm{CEC}, \mathrm{P}, \mathrm{K}, \mathrm{OM}, \mathrm{Ca}, \mathrm{Mg}, \mathrm{SiO}_{2}, \mathrm{Al}_{2} \mathrm{O}_{3}$, and $\mathrm{Fe}_{2} \mathrm{O}_{3}$; along with particle size variables: clay, silt, and sand. Descriptive statistical and geostatistical analyses were carried out. The coefficient of variation (CV) was high for most of the variables, with the exception of $\mathrm{pH}$ with a low $\mathrm{CV}$, and of sand with a medium $\mathrm{CV}$. The models fitted to the experimental semivariograms of these variables were the exponential and the spherical. The range values were from $999 \mathrm{~m}$ to $3,690 \mathrm{~m}$. For the variables $\mathrm{pH}\left(\mathrm{CaCl}_{2}\right)$, SB, and clay, there are three specific areas for land use planning. The central part of the area (zone III), where the Plintossolos Pétricos and Neossolos Flúvicos occur, is the most suitable for crops due to higher macronutrient content, organic matter and pH. Zones I and II are indicated for environmental preservation.
\end{abstract}

Keywords: geostatistics, soil chemical and physical properties, soil management. 


\title{
RESUMO: VARIABILIDADE ESPACIAL DE ATRIBUTOS DO SOLO EM UM ASSENTAMENTO DE REFORMA AGRÁRIA
}

\begin{abstract}
O estudo da variabilidade de atributos químicos e físicos do solo é muito importante para realizar seu manejo de forma adequado. Este trabalho objetivou avaliar a variabilidade espacial de atributos do solo no assentamento Malhada do Meio, para subsidiar o planejamento do uso do solo. O assentamento Malhada do Meio, localizado em Chapadinha, MA, possui uma área de 630,86 ha. A vegetação é de Floresta Estacional Decidual Submontana e Savana Estépica. A geologia é formada por arenitos e siltitos da Formação Itapecuru e por Depósitos Coluvionares e Aluvionares. O relevo é representado por colinas de topos arredondados e planos, com altitude média de $67 \mathrm{~m}$, e frequentemente recobertos por cangas ferruginosas. Coletaram-se 183 amostras de solo georreferenciadas, na profundidade de 0,00-0,20 m, em Plintossolos, Neossolo e Gleissolo. Foram analisadas as variáveis químicas: $p H\left(C a C l_{2}\right), H+A l, A l, S B$, $V, T, P, K, \mathrm{MO}, \mathrm{Ca}, \mathrm{Mg}, \mathrm{SiO}_{2}, \mathrm{Al}_{2} \mathrm{O}_{3}$ e $\mathrm{Fe}_{2} \mathrm{O}_{3}$; e as granulométricas: argila, silte e areia. Realizaram-se análises de estatística descritiva e geoestatística. $O$ coeficiente de variação $(C V)$ foi alto para a maioria das variáveis, com exceção de pH, com CV baixo, e da areia, com $C V$ médio. Os modelos ajustados aos semivariogramas experimentais dessas variáveis foram o exponencial e o esférico. Os valores do alcance variaram de 999 a $3.690 \mathrm{~m}$. Para as variáveis $\mathrm{pH}(\mathrm{CaCl})$, SB e argila, há ocorrência de três zonas específicas para o planejamento do uso do solo. A parte central da área (zona III), onde ocorrem os Plintossolos Pétricos e Neossolos Flúvicos, é a mais indicada para cultivos agrícolas, devidos aos maiores teores de macronutrientes, matéria orgânica e pH. As zonas I e II são indicadas para preservação ambiental.
\end{abstract}

Palavras-chave: geoestatística, atributos químicos e físicos, manejo do solo.

\section{INTRODUCTION}

From 1900 to $2011,8,865$ agrarian reform settlement projects were implemented in Brazil, encompassing an area of $87,559,858.95$ ha, benefitting 931,730 families (Brasil, 2012). In Maranhão State, 952 settlement projects were implemented in an area of 4,600,598.87 ha, with 124,288 families settled. Malhada do Meio, one of those settlements, practices the slash and burn system, and there is no plan for soil use and management.

Land use without adequate planning leads to soil impoverishment and low crop yield, which results in a decline in the socioeconomic and technological level of the rural population (Rampim et al., 2012). Therefore, to undertake soil planning for use and management purposes, it is important to evaluate how the chemical and physical properties of the soil are distributed in a determined area.

A tool often used to analyze how soil properties are spatially distributed in an area is geostatistics. It is effective for understanding the magnitude and structure of the spatial variability of the physical and chemical properties (Wojciechowski et al., 2009). The study of spatial variability of soil chemical and physical properties is important for agriculture because it aims to minimize the effects of variability on crop yield, optimizing the agricultural production systems (Molin, 2000).

In areas of native vegetation, the use of spatial variability may be found in the studies of Bekele and Hudnall (2006), Wojciechowski et al. (2009), and Skorupa et al. (2012). Cavalcante et al. (2007), Nascimento and Landim (2009), and Silva
Neto et al. (2011) evaluated spatial variability in different forms of soil use and management, and Carvalho et al. (2010) analyzed variability relation to environmental factors.

In agrarian reform settlements, the spatial variability of soil properties for purposes of agricultural use has not been the object of many studies, as in the case of the study undertaken by Valladares et al. (2006), who analyzed the spatial relation between the technical effectiveness of the rice crop and some properties related to soil fertility.

The aim of this study was to apply geostatistical techniques of soil chemical and physical properties to the agrarian reform settlement of Malhada do Meio in an area of native vegetation in the municipality of Chapadinha, Maranhão, Brazil, to assist in soil use planning.

\section{MATERIAL AND METHODS}

The study was carried out in the agrarian reform settlement of Malhada do Meio, located in the municipality of Chapadinha, MA, Brazil, with central coordinates (UTM) of $9585546 \mathrm{~W}$ and $661510 \mathrm{~S}$, with a mean altitude of $67 \mathrm{~m}$ and an area of 630.86 ha. The geological substrate consists of sandstones, siltstones, and ferruginous duricrusts of the Formação Itapecuru (Itapecuru Formation - Upper Cretaceous) and of sands, colluvial waterway of the Depósitos Aluvionares and Coluvionares (alluvial and colluvial deposits - Cenozoic-Quaternary-Holocene) (Vasconcelos et al., 2004). The relief is rounded 
top hills of low altitude (Figure 1), frequently covered over by ferruginous duricrusts of varied dimensions. The predominant soil is Plintossolo Pétrico Concrecionário êndico latossólico, followed by Plintossolo Argilúvico Distrófico abrúptico gleissólico, Neossolo Flúvico, and Gleissolo Háplico Tb Distrófico cambissólico, classified according to Santos et al. (2013). Vegetation, according to the classification of Veloso et al. (1991), is Floresta Estacional Decidual Submontana (seasonal submontane deciduous forest) (the largest area), with the occurrence of Babassu palm; and Savana Estépica (steppe savanna) (Park and Tree), with the occurrence of Carnauba palm.

Climate in the region according to the Thornthwaite (1948) classification is $\mathrm{C}_{2}$ WA'a', with annual rainfall from 1,600 to $2,000 \mathrm{~mm}$, and mean annual temperature ranging from 26 to $27^{\circ} \mathrm{C}$ (Maranhão, 2002).

In Malhada do Meio, there are 38 farm families that acquired the area through land credit. The production system consists of intercropping of cassava, rice, corn, and common bean; the manufacture of cassava meal; raising of small to medium-sized animals in an extensive manner (poultry, pigs, and sheep); extraction of babassu palm (most important); hunting wild animals (agouti, paca, and armadillo); and fishing. The cropped area is approximately 1-ha per family, which consists of slashing and burning the vegetation, construction of a fence to avoid the entrance of domestic animals, planting, hoeing, and, or, application of herbicide, and harvest. After two years, when rice, corn, common bean, and, finally, cassava root have been harvested, the area is abandoned and remains fallow. After some years, the vegetation is once more cut down for planting new crops. The families grew rice for three consecutive years in an area of 65 ha with the use of mechanization, lime, and fertilizers, but the area was abandoned more than five years ago due to lack of technical assistance and credit.

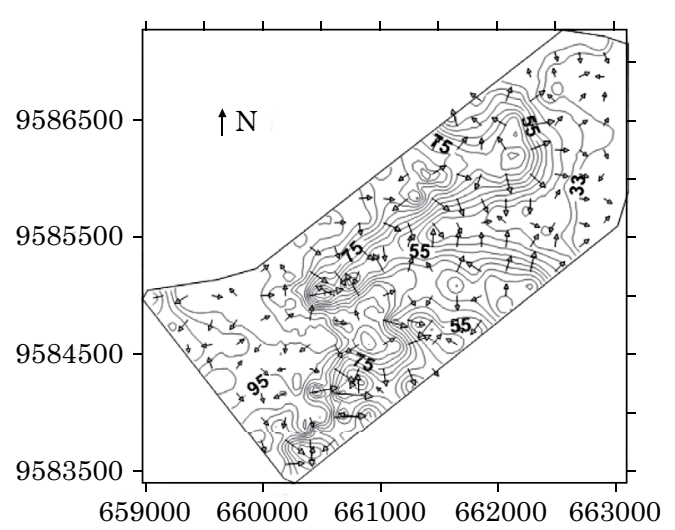

Figure 1. Elevation map with vectors of the different contour lines in the agrarian reform settlement.
Soil samples were collected and georeferenced at the depth of $0.00-0.20 \mathrm{~m}$ in an irregular grid, with 92 points at a distance of $300 \mathrm{~m}$ and in five densifications, distributed in a manner representative of the total area, and 91 points at a distance of $150 \mathrm{~m}$, for a total sampling network of 183 points. Sixteen more points were sampled for external validation (Figure 2). The $\mathrm{pH}$ values (in $\mathrm{CaCl}_{2}$ ), $\mathrm{P}$ (resin method), $\mathrm{K}, \mathrm{Ca}, \mathrm{Mg}, \mathrm{H}+\mathrm{Al}$, and $\mathrm{Al}$ were determined by the methods of Raij et al. (1987), OM determined according to Raij et al. (2001), and the values of $\mathrm{SiO}_{2}, \mathrm{Al}_{2} \mathrm{O}_{3}$, and $\mathrm{Fe}_{2} \mathrm{O}_{3}$ by the method of Embrapa (1997). Soil particle size analysis was carried out by the pipette method, using a $0.1 \mathrm{~mol} \mathrm{~L}^{-1} \mathrm{NaOH}$ solution as a chemical dispersant, and mechanical shaking at low rotation for $16 \mathrm{~h}$ (Embrapa, 1997). The clay fraction was separated by sedimentation, coarse and fine sands were separated by sieving, and silt was calculated by the difference.

Initially, the variability of the data was analyzed by descriptive statistics, with calculation of the mean, median, maximum, minimum, standard deviation, asymmetry, kurtosis, and coefficient of variation, to identify possible atypical values and the manner of distribution of the variables. Spatial dependence was modeled by fitting the theoretical mathematical models possible for the experimental semivariograms. The choice of these models was mainly based on cross validation, on the lowest RSS (Residual Sum of Squares), and on the greatest coefficient of determination $\left(\mathrm{R}^{2}\right)$. In cross validation, all the modeling decisions of the semivariogram (choice of model, direction, and number of neighbors) were tested. Having defined the models, the data were interpolated (ordinary kriging) to create spatial pattern maps.

In external validation, the values estimated by Ordinary Kriging (OK) were compared to the values observed in the 16 sampling points. To do so, the equations of the Root Mean Square Error (RMSE)

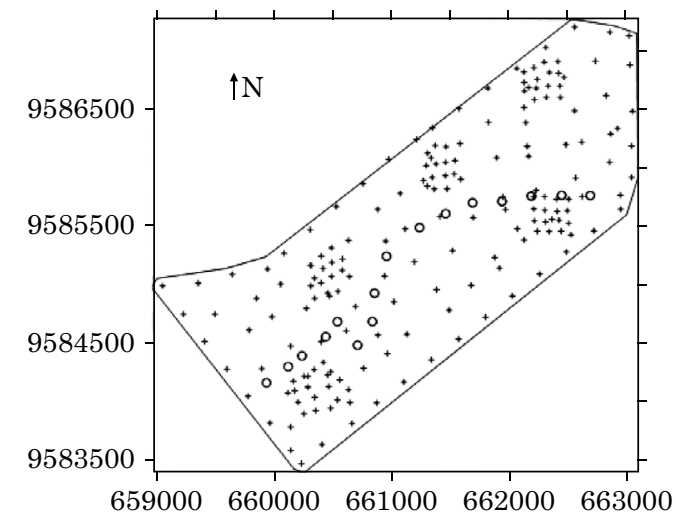

Figure 2. Sampling network $(+)$ and points sampled for external validation $(\circ)$ in the agrarian reform settlement. 
$R M S E=\left\{\frac{1}{n} \sum_{i=1}^{n}[Z(X i)-\hat{\mathrm{z}}(X i)]^{2}\right\}^{0.5}$

and of the Mean Absolute Error (MAE) were used.

$M A E=\frac{\sum_{i=1}^{n}|Z(X i)-\hat{\mathrm{z}}(X i)|}{n}$

In which $\mathrm{n}$ is the number of values used in the validation; $\mathrm{z}\left(\mathrm{x}_{\mathrm{i}}\right)$ is the value of the property at point $\mathrm{i}$, and $\hat{z}\left(\mathrm{x}_{\mathrm{i}}\right)$ is the estimated value of the property by $\mathrm{OK}$ at point $\mathrm{i}$. Lower values of RMSE and MAE are related to greater accuracy and to greater precision in the estimates, respectively.

The following programs were used: Minitab, GS+ version 9 (Robertson, 1998), and the program Surfer version 9 (Golden Software, 1999).

The degree of spatial dependence (DSD) was calculated by the formula [DSD $=\left(\mathrm{C}_{0} /\left(\mathrm{C}_{0}+\mathrm{C}_{1}\right) \times 100\right]$ developed by Cambardella et al. (1994), with the following classification: strong, if $\mathrm{DSD} \leq 25 \%$; moderate, if $26 \%<\mathrm{DSD}<75 \%$, and weak, if DSD $\geq 75 \%$.

\section{RESULTS AND DISCUSSION}

There were no significant differences between the two sets of data, sampling network $(n=183)$, and external validation $(n=16)$ by the t test $(p>0.05)$ for the variables studied.
The results in reference to the Kolmogorov-Smirnov test indicated normality for most of the variables. The variables $\mathrm{pH}\left(\mathrm{CaCl}_{2}\right), \mathrm{H}+\mathrm{Al}, \mathrm{CEC}$, and $\mathrm{V}$ showed values near each other for mean and median, which indicates that these variables do not show accentuated asymmetry (Table 1). In geostatistics, the normality of the data is not a requirement, although variables with a very high asymmetry may compromise the analyses (Cressie, 1991). The variables OM, K, Ca, Mg, SB (sum of bases), CEC (cation exchange capacity), sand, and clay show sharper asymmetry with some problems of atypical values. For these variables, logarithmic transformation was used. For the variables $\mathrm{P}$, $\mathrm{H}+\mathrm{Al}, \mathrm{Al}, \mathrm{V}, \mathrm{Al}_{2} \mathrm{O}_{3}$, and $\mathrm{Fe}_{2} \mathrm{O}_{3}$, which show a small difference between the mean and median, i.e., a small asymmetry, square root transformation was used (Webster and Oliver, 1990).

Most of the coefficients of variation (CV) of the variables, classified according to Warrick and Nielsen (1980), had high values, except for $\mathrm{pH}\left(\mathrm{CaCl}_{2}\right)$, with low $\mathrm{CV}$, and sand, with a medium CV. The high variations of the properties studied may be attributed to variations in relief, soil types, the different ages of the vegetation on the land in regrowth, and the composition of the plant litter. The low value $\mathrm{CV}$ of $\mathrm{pH}\left(\mathrm{CaCl}_{2}\right)$ may be due to the buffer effect of organic matter and the absence of alkaline soils, and the medium CV of the sand is probably due to the fact that the sand is more difficult to be transported compared to silt and clay, particles that are smaller.

Table 1. Descriptive statistics of the chemical and particle size variables studied in the agrarian reform settlement

\begin{tabular}{|c|c|c|c|c|c|c|c|c|}
\hline Variable & Mean & Median & Maximum & Minimum & SD & Asymmetry & Kurtosis & $\mathrm{CV}$ \\
\hline & & & & & & & & $\%$ \\
\hline $\mathrm{pH}\left(\mathrm{CaCl}_{2}\right)$ & 4.2 & 4.2 & 5.1 & 3.5 & 0.33 & 0.29 & -0.3 & 7.84 \\
\hline $\mathrm{P}\left(\mathrm{mg} \mathrm{dm}^{-3}\right)$ & 6.66 & 6 & 14 & 3 & 2.23 & 0.76 & 0.3 & 33.46 \\
\hline $\mathrm{OM}\left(\mathrm{g} \mathrm{dm}^{-3}\right)$ & 33.6 & 33 & 69 & 9 & 14.57 & 0.4 & -0.58 & 43.37 \\
\hline $\mathrm{K}^{+}\left(\mathrm{mmol}_{\mathrm{c}} \mathrm{dm}^{-3}\right)$ & 1.5 & 1.3 & 4.3 & 0.4 & 0.81 & 1.2 & 1.19 & 54.78 \\
\hline $\mathrm{Ca}^{2+}\left(\mathrm{mmol}_{\mathrm{c}} \mathrm{dm}^{-3}\right)$ & 14 & 12 & 47 & 3 & 9.3 & 1.21 & 1.43 & 66.36 \\
\hline $\mathrm{Mg}^{2+}\left(\mathrm{mmol}_{\mathrm{c}} \mathrm{dm}^{-3}\right)$ & 8.6 & 8 & 30 & 2 & 5.54 & 1.29 & 1.8 & 63.97 \\
\hline $\mathrm{Al}^{3+}\left(\mathrm{mmol}_{\mathrm{c}} \mathrm{dm}^{-3}\right)$ & 6.82 & 4 & 56 & 0 & 7.34 & 2.81 & 12.3 & 107.63 \\
\hline $\mathrm{H}+\mathrm{Al}\left(\mathrm{mmol}_{\mathrm{c}} \mathrm{dm}^{-3}\right)$ & 68.15 & 64 & 150 & 28 & 25.05 & 0.53 & -0.12 & 36.76 \\
\hline $\mathrm{SB}\left(\mathrm{mmol}_{\mathrm{c}} \mathrm{dm}^{-3}\right)$ & 26.19 & 22.4 & 80.3 & 5.5 & 16.88 & 1.3 & 1.46 & 63.71 \\
\hline $\mathrm{CEC}\left(\mathrm{mmol}_{\mathrm{c}} \mathrm{dm}^{-3}\right)$ & 91.13 & 91.5 & 199.8 & 33.6 & 28.77 & 0.34 & 0.18 & 31.57 \\
\hline V (\%) & 25.62 & 26 & 57 & 4 & 10.89 & 0.18 & -0.31 & 42.51 \\
\hline Clay $\left(\mathrm{g} \mathrm{kg}^{-1}\right)$ & 188.29 & 186.5 & 346 & 75 & 62.62 & 0.43 & -0.48 & 33.26 \\
\hline Silt $\left(\mathrm{g} \mathrm{kg}^{-1}\right)$ & 176.6 & 171 & 344 & 56 & 68.5 & 0.61 & -0.33 & 38.79 \\
\hline Sand (g kg-1) & 632.33 & 653 & 834 & 342 & 96.58 & -0.45 & -0.21 & 15.27 \\
\hline $\mathrm{SiO}_{2}(\%)$ & 5.89 & 5.47 & 13.7 & 0.05 & 3.518 & 0.23 & -0.65 & 59.73 \\
\hline $\mathrm{Al}_{2} \mathrm{O}_{3}(\%)$ & 8.6 & 8 & 19 & 1.5 & 4.35 & 0.5 & -0.63 & 50.34 \\
\hline $\mathrm{Fe}_{2} \mathrm{O}_{3}(\%)$ & 1.5 & 1.05 & 5.66 & 0.12 & 1.2 & 1.39 & 1.49 & 81.18 \\
\hline
\end{tabular}

$\mathrm{pH}$ values (0.01 mol L-1 $\mathrm{CaCl}_{2}$ ), P (resin method), $\mathrm{K}, \mathrm{Ca}, \mathrm{Mg}, \mathrm{H}+\mathrm{Al}$, and $\mathrm{Al}$ (Raij et al. (1987); OM (Raij et al., 2001); and the values of $\mathrm{SiO}_{2}, \mathrm{Al}_{2} \mathrm{O}_{3}$, and $\mathrm{Fe}_{2} \mathrm{O}_{3}$ (Embrapa, 1997). OM: organic matter; SB: sum of bases; CEC: cation exchange capacity; SD: standard deviation; $\mathrm{CV}$ : coefficient of variation. 
High values of $\mathrm{CV}$ for most of the variables were also found by Lima et al. (2010) in an Argissolo Vermelho-Amarelo in an area of natural vegetation in the process of regeneration; by Silva Neto et al. (2011), working with a Neossolo Quartzarênico Órtico under different forms of use and management: forest, regrowth, bare soil, cropland, pasture, and cerradão (Brazilian wooded tropical savanna), who attributed the high variation to uneven application of fertilizers and soil amendments, and to decomposition of plant litter; and by Skorupa et al. (2012), in an area composed of vegetation of the campo cerrado (Brazilian open field tropical savanna), cerradão, and cerrado (Brazilian tropical savanna) in the strict sense. Low $\mathrm{CV}$ values for $\mathrm{pH}\left(\mathrm{CaCl}_{2}\right)$, were also observed in the studies of Nascimento and Landim (2009) and Lima et al. (2010), both in forest areas, and Silva Neto et al. (2011) in a forest area and in other types of vegetation.

All the variables exhibited spatial dependence, indicating that the sample design used in this study was sufficient to support decision making for proper planning of land use.
The fit of the models of the semivariograms was based on the values of the coefficients of regression of the cross validation near the coefficients of the straight line 1:1, the lower values of RSS, and the higher values of $R^{2}$, according to Robertson (1998) (Table 2). The exponential model was fitted to the variables $\mathrm{OM}, \mathrm{K}, \mathrm{Ca}, \mathrm{H}+\mathrm{Al}, \mathrm{CEC}, \mathrm{V}$, Clay, Sand, $\mathrm{SiO}_{2}, \mathrm{Al}_{2} \mathrm{O}_{3}$, and $\mathrm{Fe}_{2} \mathrm{O}_{3}$, indicating that the behavior of these variables is more erratic on a small scale. As for the spherical model that describes less erratic phenomena on a small scale (Isaaks and Srivastava, 1989), the following variables were fitted: $\mathrm{pH}, \mathrm{P}$, $\mathrm{Mg}$, SB, Al, and Silt. According to McBratney and Webster (1986), these mathematical models best fit the soil properties.

Strong degree of spatial dependence (DSD) was found for most of the following variables: OM, $\mathrm{K}$, $\mathrm{Ca}, \mathrm{H}+\mathrm{Al}, \mathrm{CEC}, \mathrm{V}$, clay, sand, $\mathrm{SiO}_{2}$, and $\mathrm{Al}_{2} \mathrm{O}_{3}$, and values of a moderate degree in $\mathrm{P}, \mathrm{Al}, \mathrm{pH}, \mathrm{Mg}, \mathrm{SB}$, silt, and $\mathrm{Fe}_{2} \mathrm{O}_{3}$ (Table 2). A similar result, finding strong DSD for most of the soil properties, was obtained by Carvalho et al. (2010) working with a Latossolo Amarelo Distrocoeso argissólico in a natural reserve, and by Silva Neto et al. (2011) in a forest area and in other types of vegetation. Strong and moderate DSD

Table 2. Models, parameters of the semivariograms, and coefficients of cross and external validation of the chemical and particle size variables studied in the agrarian reform settlement

\begin{tabular}{|c|c|c|c|c|c|c|c|c|c|c|c|}
\hline \multirow{2}{*}{ Variable } & \multirow{2}{*}{ Mod. } & \multirow{2}{*}{$\mathbf{C}_{0}$} & \multirow{2}{*}{$\mathrm{C}_{0}+\mathrm{C}_{1}$} & \multirow{2}{*}{ A } & \multirow{2}{*}{ DSD } & \multirow{2}{*}{ RSS } & \multirow{2}{*}{$\mathbf{R}^{2}$} & \multicolumn{2}{|c|}{$\mathrm{CV}$} & \multicolumn{2}{|c|}{ ECV } \\
\hline & & & & & & & & ARC & LRC & MAE & RMSE \\
\hline & & & & $\mathrm{m}$ & $\%$ & & & & & & \\
\hline $\mathrm{pH}\left(\mathrm{CaCl}_{2}\right)$ & Sph & 0.0633 & 0.1276 & 1727 & 49.61 & $4.06 \mathrm{E}-04$ & 0.90 & 0.98 & 0.08 & 0.25 & 0.31 \\
\hline $\mathrm{P}\left(\mathrm{mg} \mathrm{dm}^{-3}\right)$ & Sph & 0.1022 & 0.2054 & 1656 & 49.76 & $1.969 \mathrm{E}-03$ & 0.80 & 1.033 & -0.06 & 1.86 & 2.29 \\
\hline $\mathrm{OM}\left(\mathrm{g} \mathrm{dm}^{-3}\right)$ & Exp. & 0.0194 & 0.2138 & 2763 & 42.48 & $3.772 \mathrm{E}-03$ & 0.76 & 1.051 & 0.06 & 11.69 & 14.64 \\
\hline $\mathrm{K}^{+}\left(\mathrm{mmol}_{\mathrm{c}} \mathrm{dm}^{-3}\right)$ & Exp. & 0.0101 & 0.2572 & 2079 & 3.93 & 2.93E-03 & 0.77 & 1.092 & 0.02 & 0.47 & 0.65 \\
\hline $\mathrm{Ca}^{2+}\left(\mathrm{mmol}_{\mathrm{c}} \mathrm{dm}^{-3}\right)$ & Exp. & 0.07 & 0.496 & 2709 & 14.11 & 0.0141 & 0.75 & 1.168 & -0.12 & 6.26 & 8.33 \\
\hline $\mathrm{Mg}^{2+}\left(\mathrm{mmol}_{\mathrm{c}} \mathrm{dm}^{-3}\right)$ & $\mathrm{Sph}$ & 0.2026 & 0.5042 & 1766 & 40.18 & $3.45 \mathrm{E}-03$ & 0.95 & 1.119 & 0.1 & 3.51 & 4.97 \\
\hline $\mathrm{Al}^{3+}\left(\mathrm{mmol}_{\mathrm{c}} \mathrm{dm}^{-3}\right)$ & Sph & 0.659 & 1.352 & 1633 & 48.74 & 0.0688 & 0.83 & 1.167 & 0.13 & 2.45 & 2.88 \\
\hline $\mathrm{H}+\mathrm{Al}\left(\mathrm{mmol}_{\mathrm{c}} \mathrm{dm}^{-3}\right)$ & Exp. & 0.218 & 2.2680 & 999 & 9.61 & 0.0808 & 0.66 & 1.035 & 0.1 & 23.80 & 28.56 \\
\hline $\mathrm{SB}\left(\mathrm{mmol}_{\mathrm{c}} \mathrm{dm}^{-3}\right)$ & Sph & 0.1716 & 0.4682 & 1722 & 36.65 & $8.85 \mathrm{E}-03$ & 0.90 & 1.112 & 0.08 & 10.18 & 12.73 \\
\hline $\mathrm{CEC}\left(\mathrm{mmol}_{\mathrm{c}} \mathrm{dm}^{-3}\right)$ & Exp. & 0.0179 & 0.1208 & 1980 & 14.82 & $4.513 \mathrm{E}-04$ & 0.81 & 1.047 & 0.07 & 23.89 & 29.76 \\
\hline V (\%) & Exp. & 0.253 & 1.403 & 3690 & 18.03 & 0.0563 & 0.91 & 1.025 & 0.03 & 9.59 & 11.89 \\
\hline Clay (g kg-1) & Exp. & 0.0114 & 0.1178 & 1251 & 9.68 & $1.924 \mathrm{E}-04$ & 0.86 & 1.063 & -0.14 & 41.4 & 53.3 \\
\hline Silt (g kg-1) & Sph & 1480 & 4390 & 1687 & 33.71 & 2332885 & 0.86 & 0.981 & 4 & 49.44 & 59.60 \\
\hline Sand (g kg-1) & Exp. & 0.00193 & 0.02536 & 1467 & 7.61 & $2.301 \mathrm{E}-05$ & 0.67 & 1.004 & 0.01 & 82.97 & 102.2 \\
\hline $\mathrm{SiO}_{2}(\%)$ & Exp. & 1.22 & 12.42 & 1026 & 9.82 & 0.38 & 0.889 & 0.993 & 0.05 & 19.37 & 4.91 \\
\hline $\mathrm{Al}_{2} \mathrm{O}_{3}(\%)$ & Exp. & 0.033 & 0.612 & 1611 & 5.39 & $3.329 \mathrm{E}-03$ & 0.911 & 1.066 & 0.1 & 2.09 & 2.93 \\
\hline $\mathrm{Fe}_{2} \mathrm{O}_{3}(\%)$ & Exp. & 0.1295 & 0.276 & 2394 & 46.92 & $1.87 \mathrm{E}-03$ & 0.867 & 1.096 & 0.03 & 0.89 & 1.31 \\
\hline
\end{tabular}

pH values (0.01 mol L-1 $\mathrm{CaCl}_{2}$ ), $\mathrm{P}$ (resin method), $\mathrm{K}, \mathrm{Ca}, \mathrm{Mg}, \mathrm{H}+\mathrm{Al}$, and $\mathrm{Al}$ (Raij et al. (1987); OM (Raij et al., 2001); and the values of $\mathrm{SiO}_{2}, \mathrm{Al}_{2} \mathrm{O}_{3}$, and $\mathrm{Fe}_{2} \mathrm{O}_{3}$ (Embrapa, 1997). OM: organic matter; SB: sum of bases; CEC: cation exchange capacity. Mod.: model; Sph.: spherical; Exp.: exponential; A: range; DSD: degree of spatial dependence; RSS: residual sum of squares; R2: coefficient of determination; CV: cross validation; ARC: angular regression coefficient; LRC: linear regression coefficient; ECV: external cross-validation; MAE: mean absolute error; RMSE: root mean square error. 
is probably derived from the intrinsic characteristics of the soil, as well as by variation in the material of origin or from being an area as yet little used for agriculture (Table 2).

The soil properties ranged from $999 \mathrm{~m}$ to $3,690 \mathrm{~m}$ (Table 2), showing that there is a spatial dependence on a large scale. For values of $\mathrm{Ca}, \mathrm{Mg}, \mathrm{K}, \mathrm{SB}, \mathrm{V}$, and $\mathrm{pH}\left(\mathrm{CaCl}_{2}\right)$, the spatial distribution was similar, with higher values in the central area of the spatial pattern maps, and lower values in the areas of lower elevation, and in the hillier areas of higher elevation (Figure 3).

The highest $\mathrm{pH}\left(\mathrm{CaCl}_{2}\right)$ values were observed where the highest values of the bases are found because, according to Ronquim (2010), they have the property of raising soil $\mathrm{pH}$. A similar spatial distribution pattern was also found by Carvalho et al. (2010) among $\mathrm{Ca}, \mathrm{Mg}, \mathrm{SB}$, and $\mathrm{pH}$; and by Lima et al. (2010) among $\mathrm{pH}, \mathrm{K}, \mathrm{Ca}, \mathrm{Mg}, \mathrm{SB}$, and V.
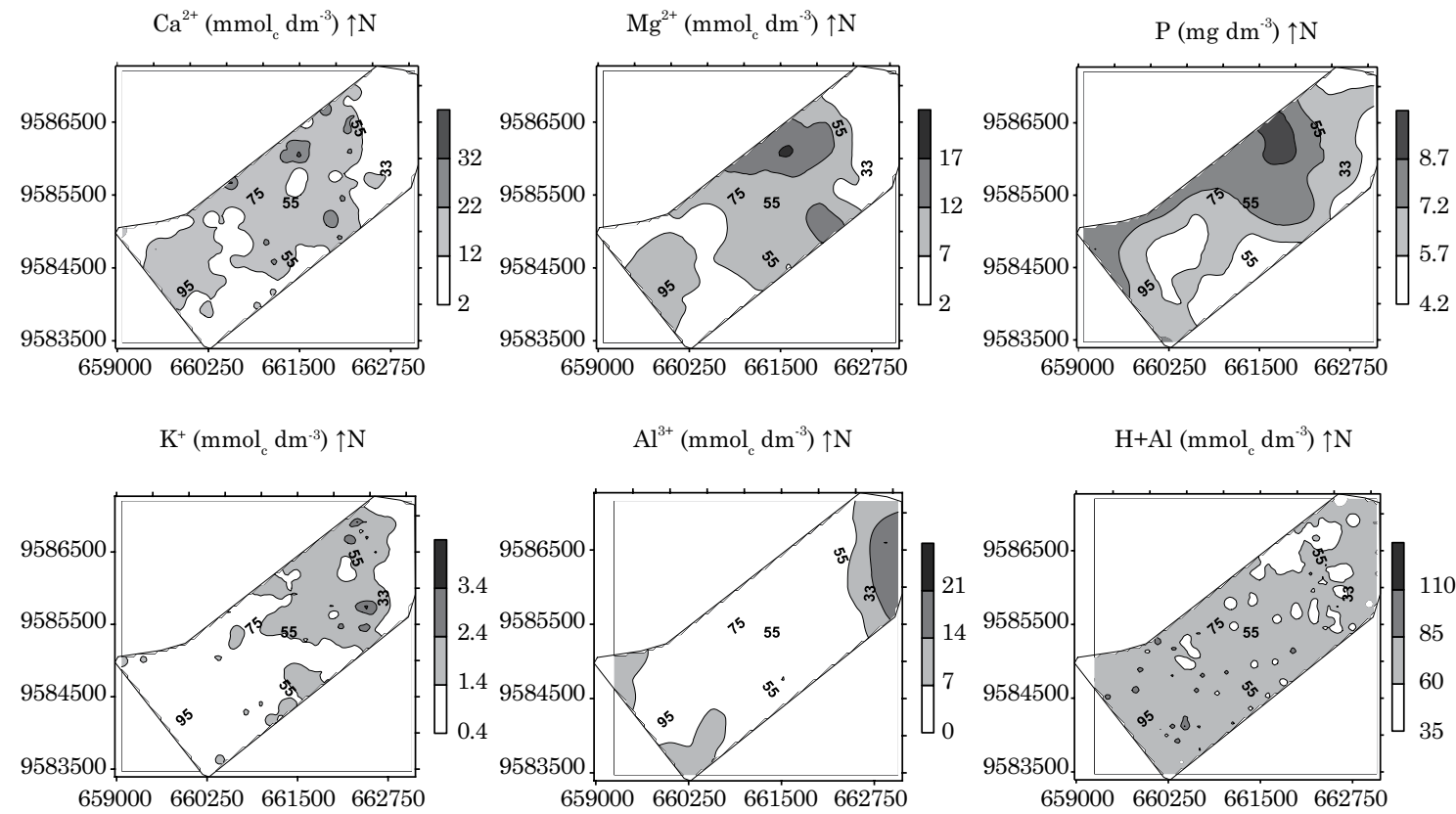

$\mathrm{SB}\left(\mathrm{mmol}_{\mathrm{c}} \mathrm{dm}^{-3}\right) \uparrow \mathrm{N}$

$\mathrm{pH} \uparrow \mathrm{N}$

$\mathrm{OM}\left(\mathrm{g} \mathrm{dm}^{-3}\right) \uparrow \mathrm{N}$
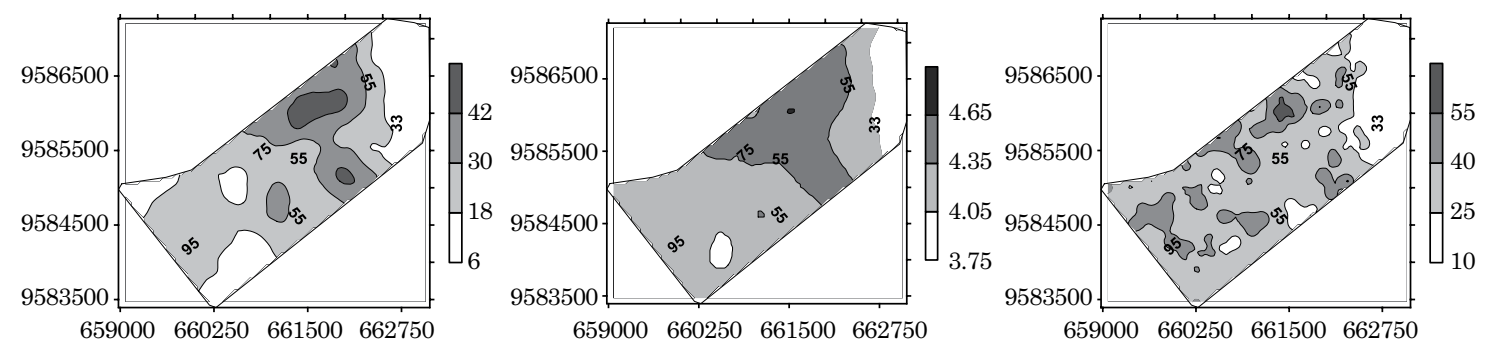

$\operatorname{CEC}\left(\mathrm{mmol}_{\mathrm{c}} \mathrm{dm}^{-3}\right) \uparrow \mathrm{N}$

$\mathrm{V}(\%) \uparrow \mathrm{N}$
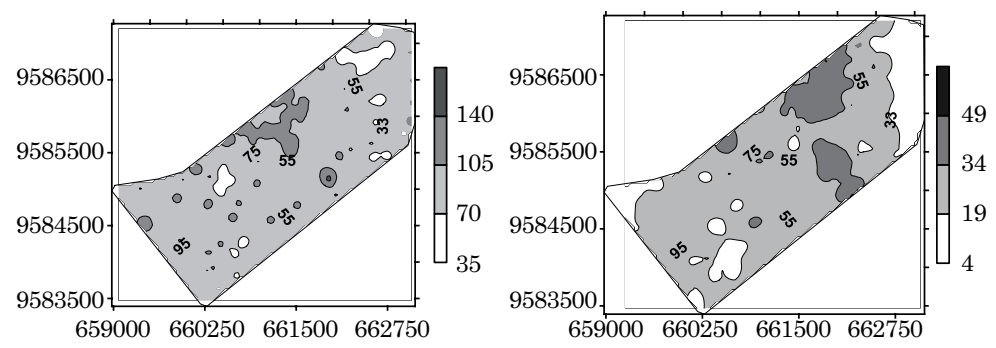

Figure 3. Spatial pattern maps for soil chemical variables in the agrarian reform settlement. 
In the central part of the spatial pattern map, higher values of $\mathrm{pH}$ were observed, coinciding with the occurrence of lower contents of $\mathrm{Al}$ and $\mathrm{H}+\mathrm{Al}$. A similar result was found by Carvalho et al. (2010) and by Lima et al. (2010), corroborating Ronquim (2010), who found that less acid soils, i.e., soils with higher $\mathrm{pH}$, have lower contents of exchangeable $\mathrm{H}$ and $\mathrm{Al}$ (Figure 3).

The coincidence of the higher values of CEC with the higher values of clay and OM shows the importance of organic matter in these soils. Organic matter may represent more than $80 \%$ of CEC in tropical soils (Ronquim, 2010). In the northwest section of the map, with forest vegetation, a greater amount of $\mathrm{OM}$ was found (greater than $30 \mathrm{~g} \mathrm{dm}^{-3}$ ) and thus the forest is probably more preserved in that location. The lowest contents of OM (less than $6 \mathrm{~g} \mathrm{dm}^{-3}$ ) were in the north, where the vegetation was steppe savanna (Figure 3 ).

The greatest amounts of the sand fraction were at the highest altitudes, from the center to the south of the area, and they showed greater variability, with values from 342 to $834 \mathrm{~g} \mathrm{~kg}^{-1}$, compatible with the rock of origin, sandstone. The greatest amounts of silt were observed in the north of the area, probably related to sediments transported by the alluvial process. The sand fraction did not show great variability, with greater amounts at the center of the area. The maximum amount of clay was $346 \mathrm{~g} \mathrm{~kg}^{-1}$, compatible with the material of origin, sandstone (Figure 4). There are ferruginous duricrusts at the top of these materials of origin.
The molecular ratios $\mathrm{SiO}_{2} / \mathrm{Al}_{2} \mathrm{O}_{3}(\mathrm{Ki})$ and $\mathrm{SiO}_{2} / \mathrm{R}_{2} \mathrm{O}_{3}(\mathrm{Kr})$ indicate a spatial pattern in the south of the area of study (Figure 4) of more weathered areas, with Ki from 0.04-1.10 and $\mathrm{Kr}$ from 0.04-0.90, most of the soils being oxidic-gibbsitic, classified according to the criteria defined by Kämpf et al. (1988) and Ker (1995). From the center to the north of the area, the ratios indicate less weathered areas, with $\mathrm{Ki}$ values ranging from 1.2-3.3 and $\mathrm{Kr}$ values from 1.00 to 2.96 , representing kaolinitic soils, according to the parameters established by Resende and Santana (1988). These values of Ki and $\mathrm{Kr}$ correspond to the occurrence of gibbsite and kaolinite, which are low activity clays, consistent with the low fertility of the area under study.

Analyzing the maps of spatial variability of chemical and physical properties, it was observed that according to the variables of $\mathrm{pH}\left(\mathrm{CaCl}_{2}\right)$, $\mathrm{SB}$, and clay, three specific zones that show similarities in their properties occur for the planning of land use. The Northeast (zone I) is an area with spatial distribution with lower amounts of the main macronutrients, $\mathrm{pH}\left(\mathrm{CaCl}_{2}\right)$ from 3.5-4.0, greater amounts of sand, more weathered soils, rolling hills with higher elevation, and the occurrence of Plintossolo Pétrico Concrecionário êndico latossólico. The Southeast (zone II) is an area with greater amounts of silt, lower amounts of organic matter, less weathered soils, flat land with lower elevation, and the occurrence of Plintossolo Argilúvico Distrófico abrúptico, Gleissolo Háplico Tb Distrófico cambissólico, and Neossolo Flúvico.
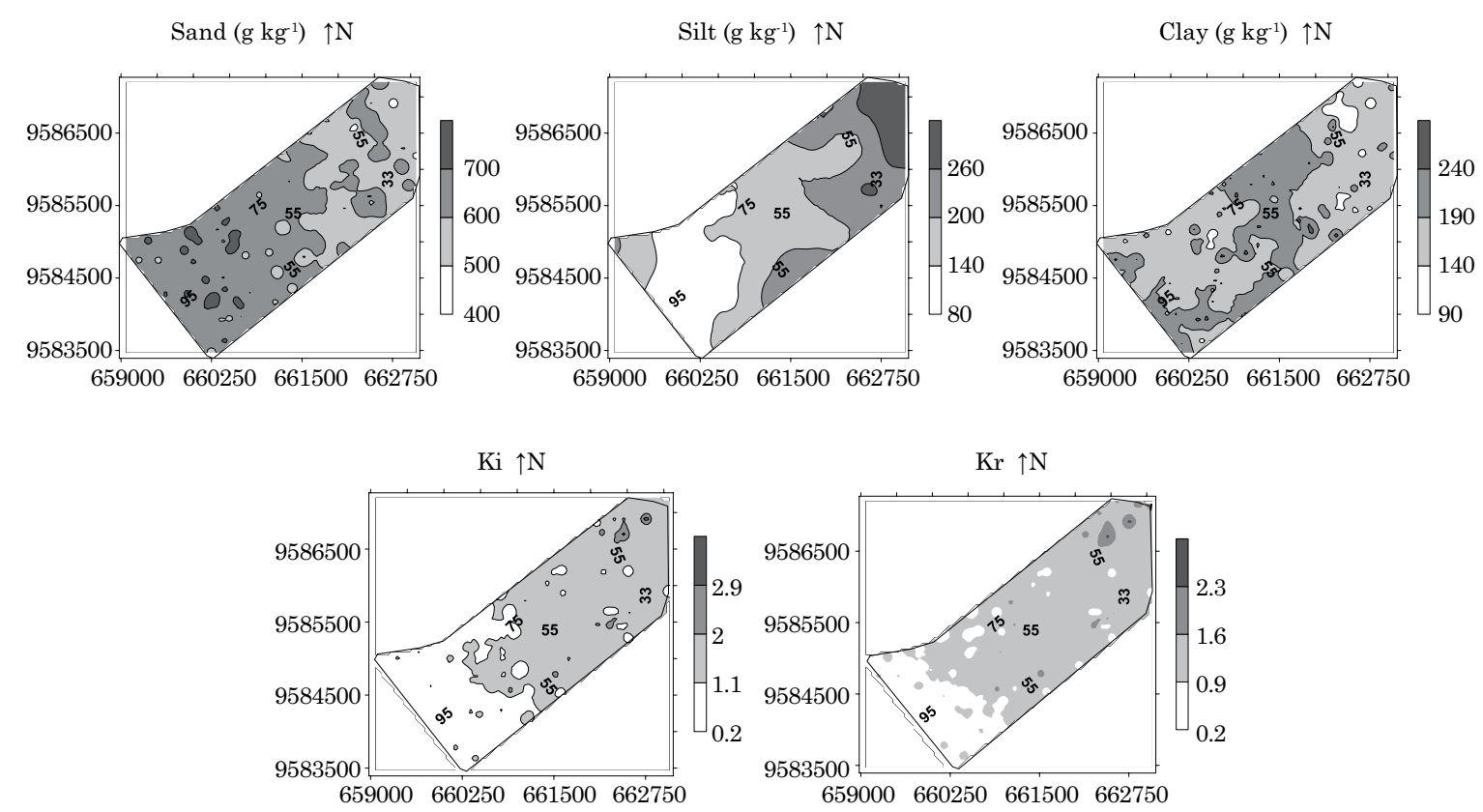

Figure 4. Spatial pattern maps for the soil particle size and the weathering indices, in the agrarian reform settlement. 
The central (zone III) part of the area shows a spatial distribution pattern with greater amounts of the main macronutrients, $\mathrm{pH}\left(\mathrm{CaCl}_{2}\right)$ from 4.3 to 5.1 , greater amounts of clay and organic matter, rolling hills with the occurrence of Plintossolo Pétrico Concrecionário êndico latossólico, and flat land with the occurrence of Neossolo Flúvico. This area is more suitable for crops, and indicates the need for smaller amounts of soil amendments and fertilizer, considerably reducing expenditures on these supplies.

\section{CONCLUSION}

This study defined homogeneous areas of the management of high and low levels of soil fertility. The central part of the area (zone III), where the Plintossolos Pétricos and Neossolos Flúvicos occur, is the most suitable for crops due to higher macronutrient content, organic matter and $\mathrm{pH}$. Zones I and II are indicated for environmental preservation.

\section{REFERENCES}

Bekele A, Hudnall WH. Spatial variability of soil chemical properties of a prairie-forest transition in Louisiana. Plant Soil. 2006;280:7-21.

Brasil. Ministério do Desenvolvimento Agrário. Instituto Nacional de Colonização e Reforma Agrária. INCRA. Projetos de reforma agrária conforme fases de implantação. 2012. [Accessed on 30 May 2013]. Available at: http://www. incra.gov.br/index.php/reforma-agraria-2/questao-agraria/ numeros-da-reforma-agraria/file/31-relacao-de-projetos-dereforma-agraria.

Cambardella CA, Moorman TB, Novak JM, Parkin TB, Karlen DL, Turco RF, Konopka AE. Fieldscale variability of soil properties in central Iowa soils. Soil Sci Soc Am J. 1994;58:1501-11.

Carvalho SRL, Vilas Boas GS, Fadigas FS. Variabilidade espacial de atributos físicos e químicos em solos originados nos sedimentos da formação Barreiras. Cad Geoci. 2010;7:63-79. [Accessed on April 21, 2013]. Available at http://www.cadernosdegeociencias.igeo.ufba.br.

Cavalcante EGS, Alves MC, Pereira GT, Souza ZM. Variabilidade espacial de atributos químicos do solo sob diferentes usos e manejos. R Bras Ci Solo. 2007;31:1329-39.

Cressie N. Statistics for spatial data. New York: John Wiley; 1991.

Empresa Brasileira de Pesquisa Agropecuária - Embrapa. Centro Nacional de Pesquisa de Solos. Manual de métodos de análise de solo. $2^{\text {a }}$.ed. Rio de Janeiro: 1997.

Golden Software Inc. Surfer for windows: Realize 7.0: contouring and 3D surface mapping for scientist's engineers user's guide. New York: 1999.

Isaaks EH, Srivastava RM. Applied geostatistics. Nova York: Oxford University Press; 1989.
Kämpf N, Klamt E, Schneider P. Óxidos de ferro em Latossolos do Brasil Sudeste e Sul. In: Anais da $3^{\text {a }}$ Reunião de Classificação, Correlação de Solos e Interpretação de Aptidão Agrícola; 1988; Rio de Janeiro. Rio de Janeiro: Embrapa/SBCS; 1988. p.153-83.

Ker JC. Mineralogia, sorção e dessorção de fosfato, magnetização e elementos traços de Latossolos do Brasil [tese]. Viçosa, MG: Universidade Federal de Viçosa; 1995.

Lima JSS, Souza GS, Silva SA. Amostragem e variabilidade espacial de atributos químicos do solo em área de vegetação natural em regeneração. R Árvore. 2010;34:127-36.

Maranhão [BR]. Governo do Estado. Gerência de Planejamento e Desenvolvimento Econômico. Universidade Estadual do Maranhão. Atlas do Maranhão. São Luís: 2002.

Mcbratney AB, Webster R. Choosing functions for semivariograms of soil properties and fitting them to sampling estimates. J Soil Sci. 1986;37:617-39.

Molin JP. Geração e interpretação de mapas de produtividade para agricultura de precisão, In: Borém A, Giúdice MP, Queiroz DM, Mantovani EC, Ferreira LR, Valle FXR, Gomide RL, editores. Agricultura de precisão. Viçosa, MG: Universidade Federal de Viçosa; 2000. p.237-58.

Nascimento GF, Landim PMB. Agricultura de precisão por metodologia geoestatística: aplicação em solos do Estado de Rondônia. In: Anais do Simpósio de Geoestatística Aplicada em Ciências Agrárias; 2009; Botucatu. Botucatu: Universidade Estadual São Paulo; 2009. [Accessed on April 21, 2013]. Available at: http://www.fca.unesp.br/sgea/Docs/19.pdf.

Raij B van, Andrade JC, Cantarella H, Quaggio JA, editores. Análise química para avaliação da fertilidade de solos tropicais. Campinas: Instituto Agronômico de Campinas; 2001.

Raij B van, Quaggio JA, Cantarella H, Ferreira ME, Lopes AS, Bataglia OC. Análise química do solo para fins de fertilidade. Campinas: Fundação Cargill; 1987.

Rampim L, Tavares Filho J, Behlau F, Romano D. Determinação da capacidade de uso do solo visando o manejo sustentável para uma média propriedade em Londrina-PR. Biosci J. 2012;28:251-64.

Resende M, Santana DP. Uso das relações Ki e Kr na estimativa da mineralogia para a classificação dos Latossolos. In: Anais do $3^{a}$ Reunião de Classificação, Correlação de Solos e Interpretação de Aptidão Agrícola, 1988; Rio de Janeiro. Rio de Janeiro; Embrapa/SBCS; 1988. p.225-32.

Robertson GP. GS + geostatistics for the environmental sciences: GS+ user's guide. Plainwell: Gamma Design Software; 1998.

Ronquim CC. Conceitos de fertilidade do solo e manejo adequado para as regiões tropicais. Campinas: Embrapa; 2010. (Boletim de Pesquisa e Desenvolvimento, 8).

Santos HG, Jacomine PKT, Anjos LHC, Oliveira VA, Lumbreras JF, Coelho MR, Almeida JA, Cunha TJF, Oliveira JB. Sistema brasileiro de classificação de solos. $3^{\text {a }}$.ed. Rio de Janeiro: Embrapa; 2013.

Silva Neto SPS, Santos AC, Leite RLL, Dim VP, Cruz RS, Pedrico AL, Neves Neto DN. Análise espacial de parâmetros da fertilidade do solo em região de ecótono sob diferentes usos e manejos. Semina: Ci. Agron. 2011;32:541-52.

Skorupa AL, Guilherme LRG, Curi N, Silva CPC, Scolforo JRS, Marques JJGSM. Propriedades de solos sob vegetação nativa em Minas Gerais: distribuição por fitofisionomia, hidrografia e variabilidade espacial. R Bras Ci Solo. 2012;36:11-22. 
Thornthwaite CW. An approach toward a rational classification of climate. Geogr Rev. 1948;38:55-94.

Valladares GS, Gomes EG, Mangabeira JAC, Grego CR, Batistella M, Miranda EE, Hott MC. Geoestatística na avaliação da fertilidade do solo e eficiência técnica para a cultura do arroz em Machadinho D'oeste, RO. In: Anais do FERTIBIO; 2006; Bonito. Bonito: Embrapa; 2006. [Accessed on Nov 10, 2013]. Available at: http://www.cnpm.embrapa. $\mathrm{br} / \mathrm{publica/download/newsdownload/artigos \_ resumos \% 20}$ anais\%20eventos/apc_27fertbio06_geoestavalfertsolomacha_ gusta.pdf.

Vasconcelos AM, Veiga Júnior J, Colares JQS, Ribeiro JAP, Gomes IP, Medeiros MF, Forgiarini LL. Folha Sa.23-São Luís. In: Schobbenhaus C, Gonçalves JH, Santos JOS, Abram MB, Leão Neto R, Matos GMM, Vidotti RM, Ramos MAB, Jesus JDA, editores. Carta Geológica do Brasil ao Milionésimo, Sistema de Informações Geográficas. Programa Geologia do Brasil [CD-ROM]. Brasília, DF: CPRM; 2004.

Veloso HP, Rangel Filho LR, Lima JC. Classificação da vegetação brasileira, adaptada a um sistema universal. Rio de Janeiro: IBGE; 1991.

Warrick AW, Nielsen DR. Spatial variability of soil physical properties in the field. In: Hillel D, editor. Applications of soil physics. New York: Academic; 1980. p.319-44.

Webster R, Oliver MA. Statistical methods in soil and land resource survey. Oxford: Oxford University Press; 1990.

Wojciechowski JC, Schumacher MV, Pires CAF, Madruga PRA, Kilca RV, Brun EJ, Silva CRS, Vaccaro S, Rondon Neto RM. Geoestatística aplicada ao estudo das características físico-químicas do solo em áreas de floresta estacional decidual. Ci Flor. 2009;19:383-91. 